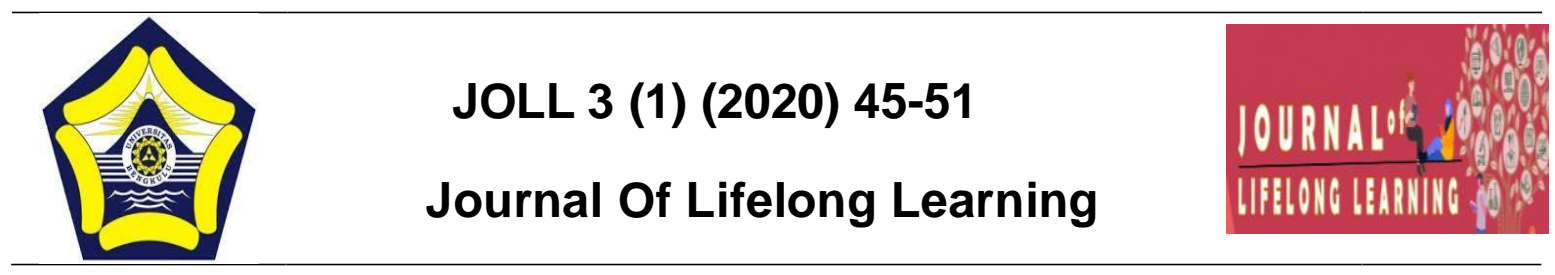

\title{
ASPIRASI PENGAMEN USIA SEKOLAH TENTANG PENDIDIKAN DAN PEKERJAAN
}

Rio Handika Saputra ${ }^{1}$, Wahiruddin Wadin'²,Parlan ${ }^{3}$

${ }^{1}$ Rio Handika, Universitas Bengkulu, Indonesia, riohandika@gamail.com

${ }^{2}$ Wahirudin Waddin, Universitas Bengkulu, Indonesia, waharidinwaddin@gmail.com

${ }^{3}$ Parlan, Universitas Bengkulu, Indonesia, parlanunib@gmail.com

\begin{abstract}
Due to the writer's thoughtfulness and according to many case studies on school age children, when these kids are supposed to go to school, they go to work. Hence, the writer is interested to conduct this research. The aim of this study is to acknowledge the perception, expectation, and efforts of school age street singers on pursuing education in Kelurahan Kebun Keling, District of Teluk Segara, City of Bengkulu. Using qualitative approach, this study was purposefully utilized case study method. Participants consisted from 6 school age street singers; two of them are in elementary school level, two of them are in junior high school level, and the rest are in senior high school level. Data was obtained through depth interview, observation, and documentation techniques; in the end, there would be conclusion drawing. To validate the data, the writer uses triangulation method on subjects, techniques, and period. The result showed that the school age street singers agree on the importance of pursuing formal education. Their perception towards formal education is assuming that one should be easier to achieve their dream jobs through their knowledge gained from their previous education. In continuation, they expect to pursue higher education so that they could get a job effortlessly. However, they have not maximized their effort to pursue better education. These mainly occur because of financial and social factors.
\end{abstract}

Key words: Perception, Expectation, Efforts, and Causal Factors

(C2020 DeptofNonformalEducationUNIB ISSN : 2715-9809

\section{$\square$ Addresscorrespondence:}

Jl.W.R.Supratman,KandangLimun,MuaraBangkaHulu,

KotaBengkulu,Bengkulu38371 


\section{PENDAHULUAN}

Pandangan, harapan dan upaya merupakan suatu keinginan untuk meraih sesuatu yang lebih tinggi dari sekarang. Dalam hal ini pandangan, harapan dan upaya yang dimiliki pengamen usia sekolah tentang pendidikan dan pekerjaan di Kelurahan Kebun Keling Kecamatan Teluk segara Kota Bengkulu.

Penelitian ini adalah pandangan, harapan dan upaya yang digali oleh peneliti bukan atas inisiatif dari pengamen usia sekolah di Kelurahan Kebun Keling Kecamatan Teluk segara Kota Bengkulu. Untuk itu dapat dirumuskan permasalahan dalam penelitian ini yaitu bagaimana pandangan pengamen usia sekolah tentang pendidikan dan pekerjaan, bagaimana harapan pengamen usia sekolah tentang pendidikan dan pekerjaan, bagaimana upaya pengamen usia sekolah tentang pendidikan dan pekerjaan dan apa faktor penyebab pengamen usia sekolah.

Menurut Walgito dalam Dukalang (2015) menyatakan bahwa pandangan atau persepsi adalah suatu proses yang didahului oleh pengindraan. Pengindraan disini merupakan suatu proses di terimannya stimulus oleh individu melalui alat indera. Proses pengindraan terjadi setiap saat, yaitu pada saat individu menerima stimulus yang mengenai dirinya melalui alat indra".

Harapan atau keinginan Dalam Riana (2015) adalah "segala sesuatu mempengaruhi yang dibutuhkan oleh seseorang dan apabila tidak terpenuhi tidak. Menurut Poerwadarminta (1990:95) dalam Witry Afrianti (2007), "Upaya adalah usaha untuk menyampaikan maksud, akal dan ikhtisar. Upaya merupakan segala sesuatu yang bersifat mengusahakan terhadap sesuatu hal supaya dapat lebih berdaya guna dan berhasil guna sesuai dengan maksud, tujuan dan fungsi serta manfaat suatu hal tersebut dilaksanakan”.

Dalam Penelitian ini upaya yang di maksudkan ialah upaya pengamen usia sekolah tentang pendidikan dan pekerjaan. Sesungguhnya ada banyak faktor yang menyebabkan anak-anak terjerumus di jalanan seperti kesulitan keuangan atau tekanan kemiskinan, ketidak harmonisan keluarga, kombinasimasalah ini sering kali memaksa anak-anak untuk mengambil inisiatif mencari nafkahatau hidup mandiri di jalanan. Kadang kala pengaruh teman atau kerabat menentukan untuk hidup di jalanan. (Kompas, 23 juli 1997).

Dalam penelitian ini faktor penyebab yang dimaksud adalah faktor 
yang menyebabkan anak sekolah tetapi juga sebagai pengamen.

\section{Metode}

Penelitian yang dilakukan yaitu penelitian kualitatif. Metode yang digunakan dalam penelitian ini ialah metode studi kasus. Subjek penelitian sebagai sumber data lebih difokuskan pada suatu penelitian, dalam arti memahami masalah dan dapat memberikan informasi sesuai dengan tujuan penelitian.Subjek penelitiannya yaitu 6 orang pengamen usia sekolah Rangga Fernandes dan Candra Mediansyah (SD), Ardianyah dan Rahmat Zain (SMP) dan Mohammad Afrizal dan Dani Ropiansah (SMK).

Teknik pengumpulan data yang digunakan dalam penelitian ini melalui wawancara, observasi dan dokumentasi. Teknik analisis data yang digunakan menurut Miles dan Huberman dalam Sugiyono (2010: 91) yaitu reduksi data, penyajian data, dan verifikasi atau menarik kesimpulan. Keabsaan data yang digunakan yaitu triangulasi subjek, waktu dan tempat, dan teknik.

\section{Hasil dan Pembahasan}

Menurut Walgito dalam Dukalang (2015) menyatakan bahwa pandangan atau persepsi adalah suatu proses yang didahului oleh pengindraan.
Dengan sekolah akan mengasah kemampuan, banyak mendapat ilmu, kawan dan yang paling penting adalah sekolah adalah langkah yang paling tepat mencapai cita-cita. Kemudian peneliti menayakan mengapa anda mengamen, dengan mengamen mendapat uang tambahan untuk jajan sekolah. Kemudian.Apa fungsi pendidikann bagi anda, Fungsi pendidikan menurut keenam informan adalah pendidikan akan meningkatkan skill, dan membentuk karakter yang baik minimal kita bisa membaca dan menulis.

Kemuadian Apa manfaat pendidikan menurut anda, untuk Memperoleh pengetahuan, cara berfikir yang baik dan mendapat gelar untuk berkarir sehingga meningkatkan taraf hidup. Kemudian Apa tujuan pendidikan menurut anda? Mengembangkan potensi dalam proses mencapai cita-cita. Kemudian Lebih penting pendidikan atau mengamen? Penting pendidikan, mengamen hanya untuk mencari uang tambahan untuk jajan sekolah.

Kemudian Siapa yang membayai sekolah anda? Orang tua kecuali Mohammad Afrizal neneknya. Berdasarkan temuan peneliti di lapangan dengan teori yang ada dapat di simpulkan 
peneliti bahwa pandangan pengamen usia sekolah tentang pendidikan dan pekerjaan yaitu Pandangan pengamen usia sekolah tentang pendidikan dan pekerjaan kelurahan Kebun Keling kecamatan Teluk Segara kota Bengkulu yaitu : pendidikan itu sangat penting, melalui pendidikan akan memperoleh ilmu pengetahuan teman dan gelar sehingga memdahkan mencapai cita-cita sedangkan pandangan mereka terhadap pekerjaan mereka ingin bekerja sesuai kemampuan, hobi dan halal.

Riana (2015), harapan atau keinginan adalah "segala sesuatu yang dibutuhkan seseorang dan apa bila tidak terpenuhi tidak mempengaruhi keiidupan orang tersebut". Maka berdasarkan hasil temuan peneliti di lapangan berdasarkan pendapat diatas dapat di simpulkan bahwa : Apa harapan anda tetang pendidikan sekarang yaitu Semoga bisa melanjutkan ke jenjang pendidikan yang lebih tinggi lalu memudahkan mendapat pekerjaan sehimgga bisa membantu ekonomi keluarga.

Kemudian Pekerjaan apa yang paling anda inginkan atau harapkan, pekerjaan yang paling diharapkan atau diinginkan adalah Rangga Fernandes citacitanya menjadii guru, Candra Mediansyah ingin menjadi Polisi, Ardiansyah ingin menjadi Polisi, Rahmat ingin mengembngkan usaha bengkel bapaknya, Mohammad Afrizal pengusaha dan Dani ingin kuliah S1 dan S2 atau langsung kerja di perusahaan atau PT.

Kemudian Jenjang pendidikan apa yang paling anda inginkan atau citacitakan jenjang pendidikan yang paling diinginkn atau diharapkan yaitu Rangga Fernandes, Candra Mediansyah, Ardiansyah, Rahmat Zain, Mohammad Afrizal dan Dani Ropiansah dapat disimpulkan bahwa jenjang pendidikan yang paling diharapkan atau dinginan adalah sarjana.

Harapan pengamen usia sekolah tentang pendidikan dan pekerjaan yaitu Rangga Fernandes ingin melanjutkan pendidikan ke jenjang selanjutnya, Candra ingin mencapai cita-citanya menjadi guru, Ardiansyah dan Rahmat Zain ingin lulus di SMA 2 kota Bengkulu, Mohammad Afrizal dan Dani ingin tamat SMK lanjut kuliah sehingga bisa sarjana sedangkan harapan pengamen usia sekolah tentang pekerjaan yaitu Rangga ingin menjadi Guru, Candra dan Ardiansyah ingin menjadi polisi, Rahmat ingin mengembangkan usaha bengkel milik bapaknya dan Mohammad Afrizal dan 
Dani Ropiansah ingin menjadi pengusahan atau bekerja di perusahaan atau PT.

Menurut Poerwadarminta (1990:95) dalam Witry Afrianti (2007), “Upaya adalah usaha untuk menyampaikan maksud, akal dan ikhtisar. Upaya merupakan segala sesuatu yang bersifat mengusahakan terhadap sesuatu hal supaya dapat lebih berdaya guna dan berhasil guna sesuai dengan maksud, tujuan dan fungsi serta manfaat suatu hal tersebut dilaksanakan".

Berdasarkan temuan peneliti di lapangan dapat disimpulakan bahwa, dari wawancara, observasi dan dokumentasi kepada keenam informan penelitian yaitu Rangga Fernandes, Candra Mediansah, Ardiansyah, Rahmat Zain, Mohammad Afrizal dan Dani Ropiansah peneliti menyimpulkan bahwa belum ada upaya maksimal yang dilakukan untuk mencapai pendidikan yang dicita-citakan

Kemudian Dari wawancara dan observasi kepada keenam informan dapat disimpulkan bahwa mereka belajar kalau ada PR sedangkan mengamen kadang sore kadang malam. Kemudian Dari wawancara dan observasi kepada keenam informan penelitian dapat disimpulkan bahwa belum ada upaya maksimal yang dilakukan subjek dalam mencapai pekerjaan yang dicita-citakan kecuali Dani Ropiansah yang sudah mencari lowongan kerja untuk mencari uang tambahan.

Kemudian dari wawancara dan observasi kepada keenam informan penelitian dapat disimpulkan bahwa yang membantu menerjakan tugas adalah orang mereka kecuali Ardiansyah mbaknya. Berdasarkan temuan peneliti dengan teori yang ada dapat disimpulkan bahwa belum ada upaya yang maksimal yang dilakukan dalam mencapai pendidikan yang diharapkan atau dicita-citakan.

Sesungguhnya ada banyak faktor yang menyebabkan anak-anak terjerumus di jalanan seperti kesulitan keuangan atau tekanan kemiskinan, ketidak harmonisan keluarga, kombinasimasalah ini sering kali memaksa anak-anak untuk mengambil inisiatif mencari nafkahatau hidup mandiri di jalanan. Kadang kala pengaruh teman atau kerabat menentukan untuk hidup di jalanan. (Kompas, 23 juli 1997).

Berdasarkan wawancara dan observasi peneliti, Orang tua Rangga Fernandes bekerja sebagai kuli bangunan atau nelayan, oang tua Candra Mediansyah bekerja sebagai nelayan, orang tua Ardiansyah bekerja sebagai buruh tambang di bengkulu utara dan ibunya bekerja di pembuatan roti kacang Anggut, 
orang tua Rahmat Zain punya usaha bengkel, Mohammad Afrizal tinggal sama neneknya yang bekerja sebagai penjual es kelapa di Tapak Padri, dan orang tua Dani Ropiansah bekerja sebagai supir gas.

Kemudian Adakah faktor orang tua menyuruh anak menjadi pengamen? Berdasarkan wawancara dan observasi peneliti peneliti menyimpulkan mengamen berdasarkan kemauannya mereka sendiri. Kemudian Bagaimana keadaan rumah pengamen usia sekolah? Berdasarkan wawancara dan observasi peneliti peneliti menyimpulkan bahwa Rangga dan keluargannya tinggal disebuah kontrakan kira-kira panjang 6 meter dan lebar 4 meter dengan harga 500 ribu perbulan, keadaan rumah Candra Candra tinggal dikontrakan, berlantai keramik, ukuran panjang 7 meter lebar 5 meter dan berdinding tembok dengan biaya perbulan 700 rb, Ardiansyah dan keluargannya tinggal disebuah kontrakan atau kosan kira-kira panjang 6 meter dan lebar 4 meter, lantai keramik, atap seng, teras 2 meter persegi dengan harga 600 ribu perbulan, Rahmat dan keluargannya tinggal disebuah rumah panjang 7 meter, berdinding papan, depanya bengkel, Afrizal tinggal sama neneknya karena orang tuannya sudah cerai keadaan beratap seng, berlantai semen, berdinding tembok, berwarna biru dan rumah Dani Ropiansah berdinding papan, berlantai semen, beratap seng, warna kuning hijau.

Kemudian apa faktor penyebab anak menjadi pengamen usia sekolah? Berdasarkan wawancara, observasi dan dokumentasi peneliti peneliti menyimpulkan Faktor ekonomi dan lingkungan.

\section{Kesimpulan}

Dari hasil di lapangan tentang pandangan, harapan dan upaya pengamen usia sekolah tentang pendidikan dan pekerjaan di Kebun Keling Kecamatan Teluk Segara Kota Bengkulu dan berdasarkan rumusan masalah, tujuan penelitian, hasil penelitian dan pembahasan maka dapat disimpulkan bahwa:

1. Pandangan pengamen usia sekolah tentang pendidikan dan pekerjaan kelurahan Kebun Keling kecamatan Teluk Segara kota Bengkulu yaitu : pandangan Rangga Fernandes dan Candra Mediansah (pengamen usia SD) yaitu karena sekolah itu penting, sepaya menjadi pintar, banyak ilmu dan mencapai cita-cita minimal bisa membaca dan menulis, pandangan Ardiansyah dan Rahmat Zain dengan sekolah memperoleh ilmu pengetahuan, 
banyak kawan dan langkah yang paling tepat untuk mencapai cita-cita dan pandanga mohammad Afrizal dan Dani Ropansah yaitu melalui pendidikan mennjadi pintar, meningkatkatkan kemampuan dan menjadi orang sukses sehingga bisa membahagiakan orang tua.

2. Harapan pengamen usia sekolah tentang pendidikan dan pekerjaan yaitu Rangga Fernandes ingin melanjutkan pendidikan ke jenjang selanjutnya, Candra ingin mencapai cita-citanya menjadi guru, Ardiansyah dan Rahmat Zain ingin lulus di SMA 2 kota Bengkulu, Mohammad Afrizal dan Dani ingin tamat SMK lanjut kuliah sehingga bisa sarjana sedangkan harapan pengamen usia sekolah tentang pekerjaan yaitu Rangga ingin menjadi Guru, Candra dan Ardiansyah ingin menjadi polisi , Rahmat ingin mengembangkan usaha bengkel milik bapaknya dan Mohammad Afrizal dan Dani Ropiansah ingin menjadi pengusahan atau bekerja di perusahaan atau PT.

3. Belum ada upaya yang maksimal yang dilakukan dalam mencapai pendidikan yang diharapkan atau dicita-citakan.

4. faktor penyebab pengamen usia sekolah adalah karena faktor ekonomi dan lingkungan (ikut-ikutan kawan).

\section{Referensi}

Basu Swastha. 2003. "Manajemen Pemasaran Modern". Yogyakarta : Liberty

Danim, Sudarwan. 2002. Penelitian

Kuantitatif dan Kualitatif. Bandung :

Pustaka Setia DR.

Depdiknas. 2002. Kamus Besar

Bahasa Indonesia. Jakarta : Balai Pustaka

Ina Primiana 2006. Usaha Kecil dan

Pengambangan. Banten : CiptaUsaha

Imaculata Umiyati 2017. Ciri

Kemandirian. Jawa Barat Yuwistara

Masrun. 1986. Faktor-faktor yang

mempengaruhi pada remaja

Sofiah et all. 2011. Sektor Usaha dan

Karakteristik. Jawa Tengah. PT Bagus

Indah

Tjitrosoepomo. 1991.Kerajinan dan Kebudayaan. Semarang : Cv Kara Bagasti

UU No. 20 Tahun 2003 tentang

Sistem Pendidikan Nasional

UUD RI No. 9 Tahun 1995 Tentang Usah Kecil. 